\title{
Updating Balanced Scorecard Model for The Evaluation of The Strategic Performance in Greater Amman Municipality
}

\author{
Fadia B. Al-haj Ahmad (PhD) \\ Sulyman H. Atieh (PhD) \\ Accounting Department, \\ World Islamic Science and Education University, Amman, Jordan
}

doi: 10.19044/esj.2016.v12n31p307 URL:http://dx.doi.org/10.19044/esj.2016.v12n31p307

\begin{abstract}
This study aimed to develop and update the model of Balance Scorecard (BSC) to measure the strategic performance efficiency at Greater Amman Municipality (GAM). In addition, the study objectives include the following: (1) To identify the availability of the BSC requirements in GAM; (2) To develop a set of measures that are in line with municipal work; and (3) To add to the BSC Model of the environmental requirements as a fifth perspective. In achieving these objectives, a questionnaire was developed based on theoretical review, previous studies, and the work experience of the authors in GAM. The questionnaire includes many items which covered five perspectives of BSC, and it was distributed to the study participants who were responsible for preparing and reviewing Strategic plan of GAM and other responsible employees in GAM. After determining the descriptive statistics and after the testing of the hypotheses, the study concluded that there is a statistical significant impact of all independent variables (customer perspective, financial perspective, environmental perspective, internal processes perspective, and learning and growth perspective) based on the efficiency of strategic performance in Greater Amman Municipality.
\end{abstract}

Keywords: Balanced Scorecard, Strategic Performance Efficiency, and Greater Amman Municipality

\section{Introduction}

In the light of the ongoing developments in the business environment, the strategic management forms the main pivot for the success of business organizations. Balanced Scorecard is considered one of the latest strategic performance assessment tools through which we establish a link between strategic objectives, initiatives, and performance indicators. In addition, BSC 
is a communication tool between the different parts of the organization, which helps to achieve a minimum level of harmony between these parts. Also, it fosters a greater understanding of the strategy and action plan by the largest number of the concerned employees. Furthermore, BSC provides a distinctive measurement style that helps organizations to measure their strategic and operating performance. Thus, it focuses on various perspectives, including the financial and non-financial sectors. BSC consists of an integrated set of performance measures which are derived from and support a company’s strategy (Kamal alddin, 2013).

BSC model was first introduced by Kaplan and Norton in 1992. However, based on the vision and strategic objectives as a basis, it was converted to a performance measure system for the purpose of evaluation for improvement. Consequently, organization strategy has been translated to four perspectives: Financial perspective, customer perspective, internal processes perspective, and learning and growth perspective. BSC system is based on integrating financial and non-financial indicators for the purpose of identifying the extent of progress in achieving the strategic objectives both quantitatively and qualitatively.

Greater Amman Municipality (GAM) is the largest municipality in Jordan. Thus, it provides municipal services that meet with its vision of being "a leading institution which aims to make Amman a modern, and safe, city that is proud of its heritage and authenticity." Also, its mission is to "provide distinctive municipal services, develop the city in such a way that strikes a balance between modernity and tradition, and adopt initiatives that serve the community and the human perspective through planning, and optimum use of resources." Furthermore, it also provides facilities to promote social work and deepen the concept of social responsibility. It is worth mentioning that GAM provides services to a geographical area of $1700 \mathrm{KM}^{2}$. Therefore, it was divided into 27 zones with a population of 2.2 million people, and with 23 thousand employees. As an independent body, Greater Amman Municipality budget for 2013 was 268.662.196 JD (www.ammancity.gov.jo).

Based on the aforementioned different statics on the size of the budget of Greater Amman Municipality and the services it provides, the two researchers decided to conduct this study. Thus, this was done using Balanced Scorecard as a modern management accounting source. Through this, its mission and strategy will be translated to a group of interrelated perspectives such as: learning perspective, internal processes perspective, customer perspective, and financial perspective. This study added new perspective to the previous four perspectives developed by Kaplan and Norton, which is the environmental perspective. Here, each perspective evaluates the performance from a different perspective. Consequently, a new 
Balanced Scorecard system that takes into consideration the five perspectives will be suggested with performance indicators. This performance indicator is in line with the nature of the work of the public sector particularly with regard to the municipal work.

\section{Statement of the Problem}

The major elements of the problem of the study are represented by the following questions:

1- What is the extent of availability of the basic requirements needed for applying Balanced Scorecard in Greater Amman Municipality?

2- What is the extent of availability of integrated measures (and indicators) for evaluating the strategic performance in Greater Amman Municipality using the Balanced Scorecard system?

3- What is the effect of using Balanced Scorecard on the strategic performance efficiency in Greater Amman Municipality?

4- What is the impact of using Balanced Scorecard approach on the strategic performance effectiveness in Greater Amman Municipality?

\section{Objectives of the Study}

The study seeks to achieve the following objectives:

1- Explaining the Balanced Scorecard approach and determining the extent of using it in municipalities which was represented by Greater Amman Municipality as a practical case.

2- Examining the five perspectives in which the balanced performance is based and finding performance measures which is consistent with municipal environment.

3- Identifying the effect of applying the Balanced Scorecard on the efficiency and effectiveness of the strategic performance.

4- Making recommendations concerning the integrated measures for strategic performance and the possibility of developing them through Balanced Scorecard in Greater Amman Municipality.

\section{Significance of the Study}

This study is significant because it examines the performance evaluation of the strategic performance in Greater Amman Municipality. Also, it tries to build a proposed BSC model with its measures and indicators which is consistent with municipal business. Perhaps, this study is one of the studies that investigated the application of Balanced Scorecard in the services sector particularly in Greater Amman Municipality. 


\section{Research Methodology and Hypotheses Research Methodology}

The descriptive and analytical method was used in this research. The related literature and the previous studies were reviewed, and the hypothesis of the research was developed. In order to achieve the objectives of the study, a questionnaire of 100 items covering the five BSC perspectives was developed and distributed to the employees in GAM.

Furthermore, a five point Likert scale was used in this study for measurement. Therefore, (1) point for lower degree and (5) points for higher degree.

\section{Hypothesis of the Study}

The First Major Hypothesis: The application requirements of Balanced Scorecard are not available in Greater Amman Municipality.

The Second Major Hypothesis: Integrated measures for the evaluation of the strategic performance using Balanced Scorecard are not available. Therefore, the following sub-hypotheses emerged from this hypothesis:

1) Integrated measures for the evaluation of the strategic performance with respect to learning and growth perspective are not available.

2) Integrated measures for the evaluation of the strategic performance with respect to the customer perspective are not available.

3) Integrated measures for the evaluation of the strategic performance with respect to the processes perspective are not available.

4) Integrated measures for the evaluation of the strategic performance with respect to the financial perspective are not available.

5) Integrated measures for the evaluation of the strategic performance with respect to the environmental perspective are not available.

The Third Major Hypothesis: Applying Balanced Scorecard does not improve the efficiency of the strategic performance.

The Fourth Major Hypothesis: Applying Balanced Scorecard does not improve the effectiveness of the strategic performance.

\section{Research Review \\ Previous Studies}

1. A study by AL-Salem (2012) was aimed at finding out the effect of applying balanced scorecard in the Jordanian customs department. The study found that applying the perspectives of the balanced scorecard is reflected positively on the institutional commitment of the Jordanian customs department workers.

2. Chan (2004) conducted a study entitled "Performance Measurement and Adoption of Balanced Scorecard: A Survey of Municipal 
Governments in the USA and Canada.” The study showed that $40 \%$ of the respondents have sufficient understanding of the importance of the Balanced Scorecard in measuring performance. However, it also showed that there were some problems in the implementation of Balanced Scorecard. For instance, the departments of local government are occupied by achieving short term goals due to the lack of participation of administration in determining the overall strategy of the organization and in identifying its long term goals.

3. Gomes et al. (2008) conducted a study entitled "Performance approach in Brazilian Small-Scale Municipalities using the Balanced Scorecard as a Feasible Tool.” The study found that there is a possibility to apply Balanced Scorecard successfully in the public sector by making the necessary adjustments to suit the working environment of that sector, particularly with regard to the financial and customer perspective.

4. Weich \& Alkhan (2010) conducted a study entitled "implementing Balanced Scorecard in a Municipality Setting - and they Lived Happily ever after: A case study of the city of Copenhagen.” One of the most important findings of the study is the Municipal success of applying the four perspectives as they are developed by Kaplan and Norton in 1992. However, the study also showed that three departments decided not to implement Balanced Scorecard because of the weakness in their information technology and their inability to get the data needed for applying Balanced Scorecard.

5. Northcott (2011) conducted a study entitled "Using the Balanced Scorecard to Manage Performance in Public Sector Organizations - Issues and Challenges (practical case in the local government organizations in New Zealand)." However, the results of this study indicated that there is a decline in the use of the Balanced Scorecard by public sector organizations involved in the study. The study figured out the most important obstacles in applying the Balanced Scorecard in the public sectors. Thus, these obstacles include the fact that the traditional perspective of the Balanced Scorecard is inadequate to the public sector, especially the customer perspective. Also, it also entails the inability to identify the effective relationship between cause and effect which is related to determining the performance measures.

6. Karimi Muriruri \& Kilika (2015) conducted a study entitled "The influence of the Balanced Scorecard on Performance of Public Sector Organization in Kenya." The study was designed to establish the extent to which the dimensions of the BSC has been implemented in some selected public sectors in Kenya and how they are likely to explain variation in the performance of the organizations. The descriptive results indicated that financial, internal business process, and customers focus were rated relatively high, while innovation and learning was rated at a moderate level. The four dimensions significantly predict the performance at the public 
sector organizations in Kenya. The study concluded that the Balanced Scorecard is not only a management system, but also a management tool for use by organizations to classify their vision and strategy and their translation to goals and actions.

Subsequently, previous studies cover the application of BSC in public organizations. These studies agree that BSC approach is an important tool for measuring the organizations performance except the Northcott study on New Zealand. Thus, the study indicated that there is a decline in the use of the Balanced Scorecard in the public sector.

\section{Balanced Scorecard Concept}

There are multiple definitions of Balanced Scorecard. However, the most important of these definitions is that of Kaplan and Norton (1996) ' definition: "A management system designed to help the organization to translate its vision and strategy into a set of objectives and strategic measures that are linked through four perspectives: Financial Perspective, Customer Perspective, Internal Processes Perspective, and Learning and Growth Perspective." Subsequently, Balanced Scorecard has been also defined as ""a set of financial and non-financial performance measures which provides a clear vision of the organizations performance to senior management executives" (Kaplan \& Norton, 1998). In addition, the use of the Balanced Scorecard has achieved different management objectives for organizations and administration, including the study of Kaplan and Norton (1992):

- Translating strategies into an integrated set of financial and nonfinancial performance measures.

- Helping to understand and deliver the strategic objectives of organization staffs, and stimulating them to achieve the strategic goals.

- $\quad$ Striking a balance between long and short-term goals, the financial and non-financial measures, and between internal and external standards.

- Improving the continuous performance and the effectiveness of the control process.

\section{Balanced Scorecard Perspectives}

Consequently, the perspectives of the BSC include the following:

First: Financial Perspective: The financial perspective is the main perspective in the Balanced Scorecard. This was despite the fact that most researchers criticize the financial perspective and support the non-financial perspective. It is worth mentioning that many of them consider that the ultimate goal of organization is to achieve financial goals (Niven, 2006; Alshaikh, 2007).

Second: Customer Perspective: This perspective aims to answer questions on how costumers view the organization (AL Bishtawi, 2001). It is 
the essence of non-financial perspective (Niven, 2006). This perspective focuses on providing measures to achieve the specific goals regarding customers' satisfaction and to meet their requirements in obtaining highquality products and reasonable prices through market share analysis (Kaplan \& Norton, 1996). In addition, the main focus of this perspective is to select strategies that meet customers' satisfaction and expand target market in order to enhance the competitive opportunity (Kaplan et al., 2004).

Furthermore, Kaplan and Norton (1996) determined various properties that can add value to the product from the point of view of the customer. These properties include the following:

- $\quad$ The product or service properties by obtaining the highest quality and the lowest price at the right time.

- The relationship with the client through the product and service delivery and after sales complaints.

- $\quad$ Reputation and being famous through the organization's ability to make themselves known and shows their distinctive features.

A set of general criteria can be used to measure the success of achieving the strategic objectives of clients, including: customer satisfaction metric, customer retention metric, attracting new customers metric, customer profitability metric, and market share metric (Atkinson, 2006).

Third: Internal Process Perspective: This perspective focuses on the critical operational processes and how they are carried out in such a way that they achieve organizational excellence. This perspective is associated with the customers' perspective by carrying out operational processes that achieve their desires and needs efficiently and effectively. This will be reflected on the financial perspective represented in gaining the financial resources, achieving organizational profitability, and the expected shareholders' value (Horngren et al., 2009). Mcginty (2004) demonstrated that the aim behind the internal processes perspective is to achieve efficiency, effectiveness quality, and reduce costs. Therefore, this will lead to costumers' satisfaction to increase profitability and achieve financial returns (Akel, 2002).

Forth: Learning and Growth Perspective: This perspective focuses on the infrastructure of the organization. It is represented in the human capital, regulations and regulatory actions, which are considered as an intangible asset of the organization. This perspective includes determining how the organization can continue its development and creativity, and creates a higher value by focusing on the development of personnel capacities within the organization. There are multiple measures of this perspective which include: employee satisfaction measure, staff retention measure, staff training measure, and other measures related to the efficiency of information systems used in the organization (Kaplan \& Norton, 1996). 
Other measures can be used for this perspective such as research expenses measure and information systems development measure (Turkman, 2006).

\section{Suggested Balanced Scorecard Model in Greater Amman Municipality}

The following model of Balanced Scorecard has been suggested by authors with amendments of its perspectives. Furthermore, it adds a fifth perspective (environmental perspective) because of its importance shown in the process and services provided by the Greater Amman Municipality. There has been another amendment based on the description of the customer perspective. Thus, this was such that the customer includes all service beneficiaries of Greater Amman Municipality who were identified by law including Amman residents and visitors. It also include government and nongovernment institutions besides the re-arrangement of such perspective so that the customer perspective is at the top of the Balanced Scorecard perspectives rather than financial perspective as stated in Northcott (2011) study and Mathys (2006) study. If the Balanced Scorecard is correctly constructed, the performance measures should be lined up together in a cause and effect basis.

\section{Updated Model of Balanced Scorecard in Greater Amman Municipality}

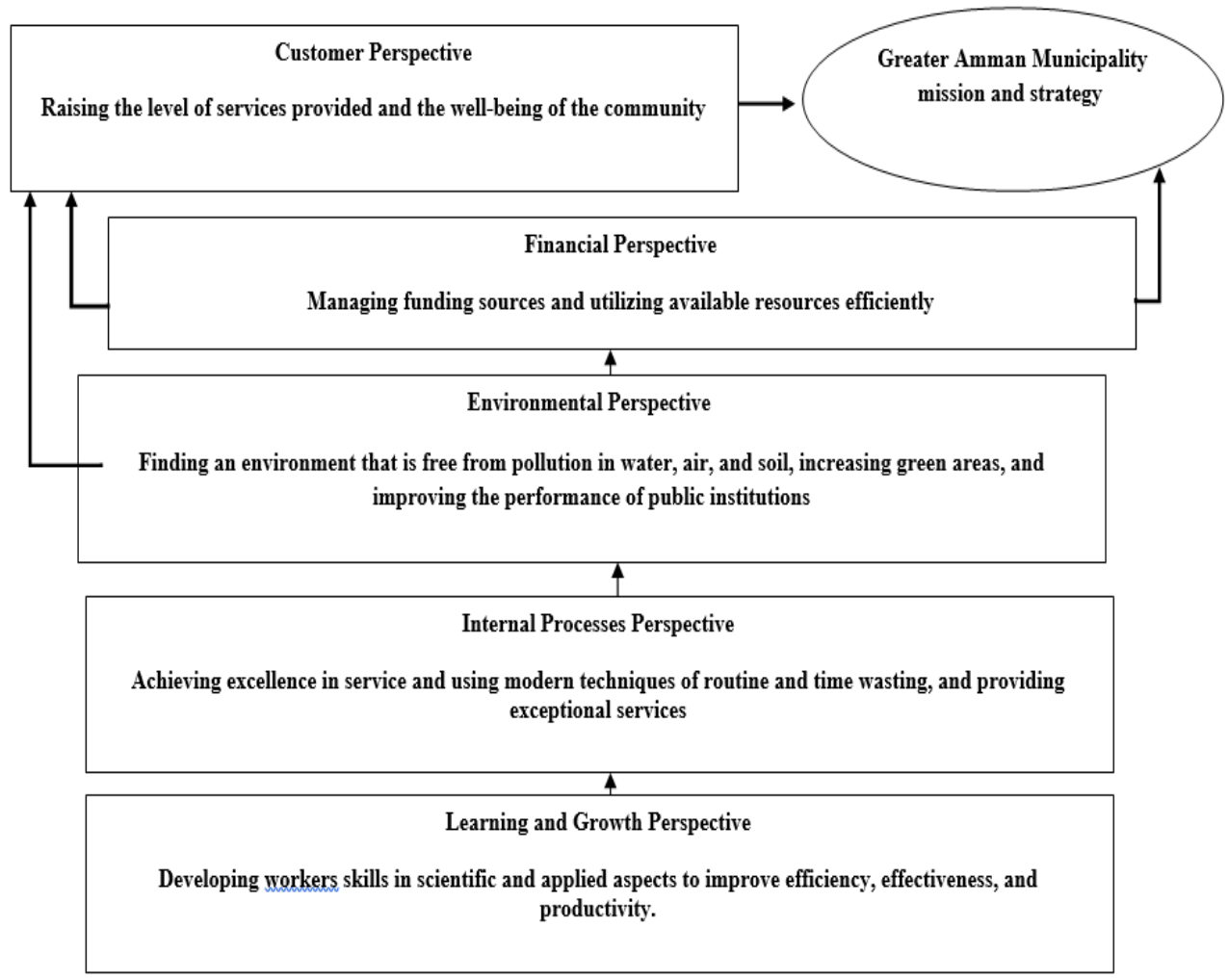


Table (1) The following performance measures are developed by the researchers of this study:

\begin{tabular}{|c|c|}
\hline 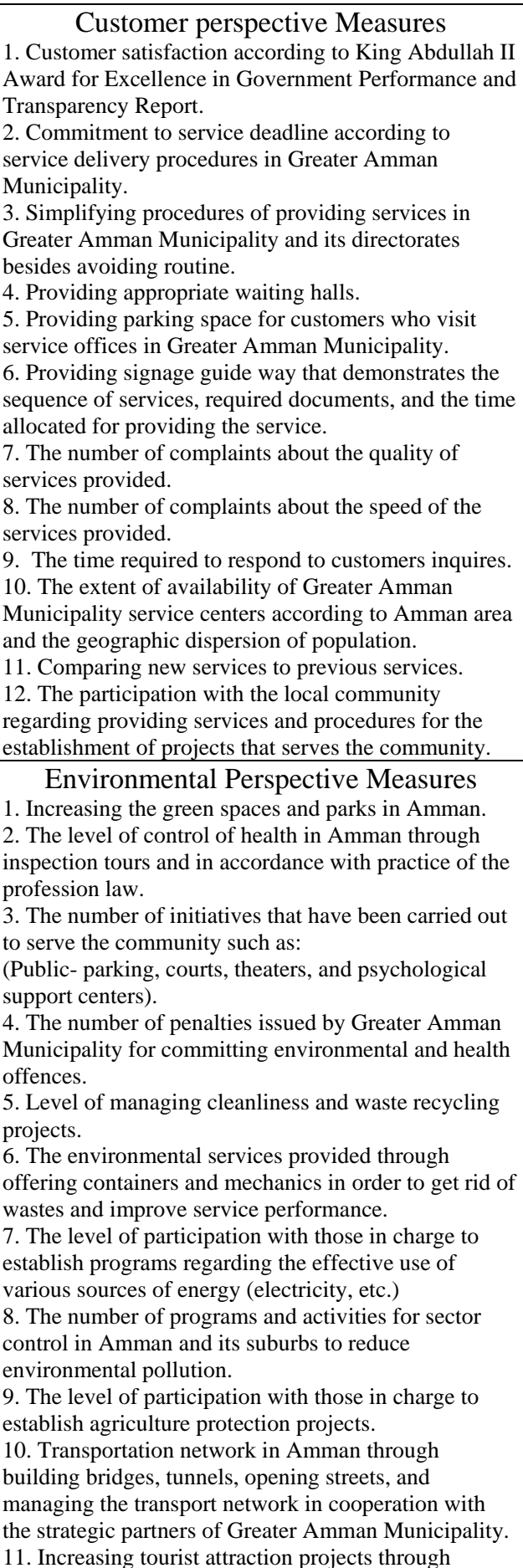 & $\begin{array}{l}\text { Internal Processes Perspective Measures } \\
\text { 1. The proportion of automated processes and the } \\
\text { creation of a unified database to facilitate information } \\
\text { exchange, saving time and cost, and providing the } \\
\text { service effectively. } \\
\text { 2. Ratio of the electronic services to the total services } \\
\text { provided at Greater Amman Municipality. } \\
\text { 3. The rate of using electronic payment when collecting } \\
\text { fees and revenues. } \\
\text { 4. The number of complaints regarding website work } \\
\text { continuity of Greater Amman Municipality. } \\
\text { 5. Number of services provided in one place. } \\
\text { 6. Comparing the number of employees who have been } \\
\text { trained during this period with previous periods. } \\
\text { 7. Comparing the number of training programs for } \\
\text { workers in Greater Amman Municipality during this } \\
\text { period with previous period. } \\
\text { 8. The number of services specified in the flow chart to } \\
\text { the total number of services provided at Greater Amman } \\
\text { Municipality. } \\
\text { 9. Greater Amman Municipality participation in the } \\
\text { competition with other government institutions in } \\
\text { accordance with the standards of the King Abdullah II } \\
\text { Award for Excellence in Government Performance. } \\
\text { 10. The existence of a clear organizational structure that } \\
\text { defines its powers and responsibilities. } \\
\text { 11. The number and quality of services listed in service } \\
\text { delivery procedures to the number of services provided } \\
\text { at Greater Amman Municipality. } \\
\text { 12. The number of studies conducted to figure out the }\end{array}$ \\
\hline
\end{tabular}


festivals, annual seminars, and cultural preservation of the heritage monuments of the city.

12. The number of projects carried out in accordance to the plans to preserve the heritage and traditional places in Amman (the amount of money spent on restoring Heritage Houses).

13. The number of investment attraction projects in Amman by facilitating licensing and offering suitable infrastructure for projects.

\section{Financial Perspective Measures}

1. The accuracy of financial forecasts and reducing the variances between the actual results and budget estimates and analyzes these results.

2. The growth in capital spending budget compared to previous periods.

3. The growth in the collection of own-revenue.

4. Property taxes compared to previous periods.

5. The extent of implementing projects as planned in the budget.

6. The extent of decline in current spending compared to previous periods because of its importance in the preparation of the budget besides focusing on capital projects to ensure the continuity of work in

Greater Amman Municipality.

7. The extent of decline in external financing cost of the current period compared to the previous periods.

8. The rate of increasing the revenue collected from Greater Amman Municipality investments or from the current period to the previous periods.

9. Implementing the financial performance appraisal system.

10. Financial incentives and bonuses, besides applying performance appraisal system, which includes promotions.

11. Cost control and efficiency in service delivery.

12. Budget spending commitment in accordance with article number and item provided in the budget law.

\section{Analysis of the Study Results \\ Descriptive Statistics}

The following table shows the general measure of the mean and the general measures of standard deviation for all items of each BSC perspective.

Table (2)

\begin{tabular}{|c|c|c|c|c|}
\hline BSC Perspectives & $\begin{array}{c}\text { No. of items of the } \\
\text { Questionnaire }\end{array}$ & Mean & $\begin{array}{c}\text { Standard } \\
\text { Deviation }\end{array}$ & $\begin{array}{c}\text { Interpretation Relative } \\
\text { Importance }\end{array}$ \\
\hline $\begin{array}{c}\text { Availability of BSC } \\
\text { Requirements at GAM }\end{array}$ & 16 & 3.003 & 0.878 & Moderate \\
\hline $\begin{array}{c}\text { Application of } \\
\text { Learning and Growth } \\
\text { Perspective at GAM }\end{array}$ & 15 & 3.008 & 0.818 & Moderate \\
\hline $\begin{array}{c}\text { Application of } \\
\text { Recipients of GAM } \\
\text { Services }\end{array}$ & 13 & 3.130 & 0.856 & Moderate \\
\hline $\begin{array}{c}\text { Application of Internal } \\
\text { Process Perspective }\end{array}$ & 15 & 3.121 & 0.869 & Moderate \\
\hline $\begin{array}{c}\text { Application of } \\
\text { Financial Perspective }\end{array}$ & 11 & 3.154 & 0.865 & Moderate \\
\hline $\begin{array}{c}\text { Application of } \\
\text { Environmental } \\
\text { Perspective }\end{array}$ & 13 & 3.017 & 0.890 & \\
\hline
\end{tabular}


The descriptive results for all BSC perspectives at GAM were related. Thus, they were relatively moderate with mean between 3.003-3.154, and standard deviation between 0.818-0.890. Also, the descriptive analysis showed that very few items which is related relatively high have the following characteristics:

- GAM has a clean vision which was translated into strategic goals with a mean of 3.541 .

- $\quad$ There was a growth in collecting Tax revenue of GAM with a mean of 5.78 .

\section{Testing of the Hypotheses}

The main hypotheses and sub hypotheses of the second hypothesis of One-sample t-test were tested. Also, the answer "Neutral" was identified and ranked in answer (3) as average reference (default). Therefore, the results were as follows:

H01: Application requirements of Balanced Scorecard are not available in Greater Amman Municipality.

Table (3). The availability of application requirements of Balanced Scorecard test

\begin{tabular}{|c|c|c|c|c|c|}
\hline $\begin{array}{c}\text { Intangible } \\
\text { Sig }\end{array}$ & $\begin{array}{c}\text { The } \\
\text { calculated } \\
\text { value of } T \\
\end{array}$ & $\begin{array}{l}\text { Standard } \\
\text { deviation }\end{array}$ & $\begin{array}{l}\text { Arithmetic } \\
\text { mean value }\end{array}$ & $\begin{array}{c}\begin{array}{c}\text { Arithmetic } \\
\text { mean } \\
\text { difference }\end{array} \\
\end{array}$ & $\begin{array}{c}\text { Availability of } \\
\text { application } \\
\text { requirements }\end{array}$ \\
\hline 0.961 & 0.049 & 0.8778 & 3.0028 & 0.0028 & $\begin{array}{l}\text { or Balanced } \\
\text { Scorecard }\end{array}$ \\
\hline
\end{tabular}

Subsequently, we noticed from the data in the table above that the arithmetic mean of the availability of Balanced Scorecard application requirements in Amman Municipality was 3.0028. Thus, this is larger than the default arithmetic mean adopted by a researcher (3). The difference is 0.0028. Such difference has no significance based on the value of significance (Sig $=0.961$ ) which is greater than 0.05 . This indicates the nonapproval of the availability of Balanced Scorecard application requirements in Amman Municipality. It also confirms the first major hypotheses which states that Balanced Scorecard application requirements in Amman Municipality are not available.

H02: Integrated measures for evaluating the strategic performance using Balanced Scorecard are not available.

Its sub-hypotheses were tested as follows: Integrated measures for the evaluation of the strategic performance with respect to learning and growth perspective are not available.

H02-1: Greater Amman Municipality does not implement learning and growth measures. 
Table (4). Testing the application of learning and growth measures in Amman Municipality

\begin{tabular}{|c|c|c|c|c|c|}
\hline $\begin{array}{l}\text { Intangible } \\
\text { Sig }\end{array}$ & $\begin{array}{c}\text { The } \\
\text { calculated } \\
\text { value of } T \\
\end{array}$ & $\begin{array}{l}\text { Standard } \\
\text { deviation }\end{array}$ & $\begin{array}{l}\text { Arithmetic } \\
\text { mean value }\end{array}$ & $\begin{array}{c}\begin{array}{c}\text { Arithmetic } \\
\text { mean } \\
\text { difference }\end{array} \\
\end{array}$ & $\begin{array}{c}\text { Applying } \\
\text { learning and } \\
\text { growth }\end{array}$ \\
\hline 0.885 & 0.145 & 0.8178 & 3.0078 & 0.0078 & $\begin{array}{c}\text { Amman } \\
\text { Municipality }\end{array}$ \\
\hline
\end{tabular}

Subsequently, we noticed from the data in the table above that the arithmetic mean of applying learning and growth measures in Amman Municipality was 3.0078. Thus, this is larger than the default arithmetic mean adopted by a researcher (3). The difference is 0.0078 . Such difference has no significance based on the value of significance $(\mathrm{Sig}=0.885)$ which is greater than 0.5. Thus, this indicates the approval of implementing learning and growth perspective measures. It also confirms the first major subhypotheses which states that learning and growth perspective measures are not implemented in Greater Amman Municipality.

H02-2: Greater Amman Municipality does not implement customer perspective measures.

Table (5). Testing the application of Customer Perspective measures in Amman Municipality

\begin{tabular}{|c|c|c|c|c|c|}
\hline $\begin{array}{c}\text { Intangible } \\
\text { Sig }\end{array}$ & $\begin{array}{c}\text { The } \\
\text { calculated } \\
\text { value of } T\end{array}$ & $\begin{array}{l}\text { Standard } \\
\text { deviation }\end{array}$ & $\begin{array}{l}\text { Arithmetic } \\
\text { mean value }\end{array}$ & $\begin{array}{c}\text { Arithmetic } \\
\text { mean } \\
\text { difference }\end{array}$ & $\begin{array}{c}\text { Applying } \\
\text { Customer } \\
\text { Perspective }\end{array}$ \\
\hline 0.015 & 2.454 & 0.8562 & 3.1388 & 0.1388 & $\begin{array}{c}\text { Amman } \\
\text { Municipality }\end{array}$ \\
\hline
\end{tabular}

Subsequently, we noticed from the data in the table above that the arithmetic mean of applying customer perspective measures in Amman Municipality was 3.1388. Thus, this is larger than the default arithmetic mean adopted by a researcher (3). The difference is 0 . 1388. Such difference has no significance based on the value of significance ( $\mathrm{Sig}=0.015)$ which is smaller than 0.5. This indicates rejecting the second sub-hypothesis and accepting the alternative hypothesis, which states that customer perspective measures are implemented in Greater Amman Municipality.

H02-3: Greater Amman Municipality does not implement internal processes perspective measures.

Table (6). Testing the application of internal processes perspective measures in Amman

Municipality

\begin{tabular}{|c|c|c|c|c|c|}
\hline $\begin{array}{c}\text { Intangible } \\
\text { Sig }\end{array}$ & $\begin{array}{l}\text { The } \\
\text { calculated } \\
\text { value of } T \\
\end{array}$ & $\begin{array}{l}\text { Standard } \\
\text { deviation }\end{array}$ & $\begin{array}{l}\text { Arithmetic } \\
\text { mean value }\end{array}$ & $\begin{array}{c}\text { Arithmetic } \\
\text { mean } \\
\text { difference } \\
\end{array}$ & $\begin{array}{c}\text { Applying internal } \\
\text { processes } \\
\text { perspective }\end{array}$ \\
\hline 0.036 & 2.107 & 0.8687 & 3.1210 & 0.1210 & $\begin{array}{l}\text { Amman } \\
\text { Municipality }\end{array}$ \\
\hline
\end{tabular}


Subsequently, we noticed from the data in the table above that the arithmetic mean of applying internal processes perspective measures in Amman Municipality was 3.1210. Thus, this is larger than the default arithmetic mean adopted by a researcher (3). The difference is 0.1210 . Such difference has no significance based on the value of significance (Sig = 0.036) which is smaller than 0.5. This indicates rejecting the third subhypothesis and accepting the alternative hypothesis, which states that internal process perspective measures are implemented in Greater Amman Municipality.

H02-4: Greater Amman Municipality does not implement the financial perspective measures.

Table (7). Testing the application of financial perspective measures in Amman Municipality

\begin{tabular}{|c|c|c|c|c|c|}
\hline $\begin{array}{c}\text { Intangible } \\
\text { Sig }\end{array}$ & $\begin{array}{c}\text { The } \\
\text { calculated } \\
\text { value of T }\end{array}$ & $\begin{array}{c}\text { Standard } \\
\text { deviation }\end{array}$ & $\begin{array}{c}\text { Arithmetic } \\
\text { mean } \\
\text { value }\end{array}$ & $\begin{array}{c}\text { Arithmetic } \\
\text { mean } \\
\text { difference }\end{array}$ & $\begin{array}{c}\text { Applying financial } \\
\text { perspective measures in } \\
\text { Amman Municipality }\end{array}$ \\
\hline $\mathbf{0 . 0 0 8}$ & $\mathbf{2 . 6 8 9}$ & $\mathbf{0 . 8 6 5 1}$ & 3.1537 & $\mathbf{0 . 1 5 3 7}$ & \\
\hline
\end{tabular}

Subsequently, we noticed from the data in the table above that the arithmetic mean of applying financial perspective measures in Amman Municipality was 3.1537. Thus, this is larger than the default arithmetic mean adopted by a researcher (3). The difference is 0.1537 . Such difference is not significance based on the value of significance ( $\mathrm{Sig}=0.008)$ which is smaller than 0.5. This indicates rejecting the fourth sub-hypotheses and accepting the alternative hypotheses which states that financial perspective measures are implemented in Greater Amman Municipality.

\section{H02-5: Greater Amman Municipality does not implement the environmental perspective measures.}

Table (8). Testing the application of environmental perspective measures in Amman Municipality

\begin{tabular}{|c|c|c|c|c|c|}
\hline $\begin{array}{c}\text { Intangible } \\
\text { Sig }\end{array}$ & $\begin{array}{c}\text { The } \\
\text { calculated } \\
\text { value of } T \\
\end{array}$ & $\begin{array}{l}\text { Standard } \\
\text { deviation }\end{array}$ & $\begin{array}{l}\text { Arithmetic } \\
\text { mean value }\end{array}$ & $\begin{array}{c}\begin{array}{c}\text { Arithmetic } \\
\text { mean } \\
\text { difference }\end{array} \\
\end{array}$ & $\begin{array}{c}\text { Applying } \\
\text { environmental } \\
\text { perspective }\end{array}$ \\
\hline 0.731 & 0.344 & 0.8909 & 3.0205 & 0.0205 & $\begin{array}{l}\text { Amman } \\
\text { Municipality }\end{array}$ \\
\hline
\end{tabular}

Subsequently, we noticed from the data in the table above that the arithmetic mean of applying learning and growth measures in Amman Municipality was 3.0205. Thus, this is larger than the default arithmetic mean adopted by a researcher (3). The difference is 0.0205 . Such difference has no significance based on the value of significance ( $\mathrm{Sig}=0.731)$ which is greater than 0.5 . This indicates the disapproval of implementing environmental perspective measures. It also accepts the first major subhypothesis and rejects the alternative hypothesis which states that 
environmental perspective measures are implemented in Greater Amman Municipality. After testing the aforementioned sub-categories, the major hypotheses was tested and the following results were reached:

H02: Integrated measures to evaluate the strategic performance using the Balanced Scorecard are not available

Table (9). Testing the availability of integrated measures to evaluate the strategic

performance using the Balanced Scorecard

\begin{tabular}{|c|c|c|c|c|c|}
\hline $\begin{array}{l}\text { Intangible } \\
\text { Sig }\end{array}$ & $\begin{array}{c}\text { The } \\
\text { calculated } \\
\text { value of } T \\
\end{array}$ & $\begin{array}{l}\text { Standard } \\
\text { deviation }\end{array}$ & $\begin{array}{l}\text { Arithmetic } \\
\text { mean value }\end{array}$ & $\begin{array}{c}\text { Arithmetic } \\
\text { mean } \\
\text { difference }\end{array}$ & $\begin{array}{l}\text { Availability of } \\
\text { Integrated } \\
\text { measures to }\end{array}$ \\
\hline 0.065 & 1.856 & 0.7206 & 0.0884 & 3.0884 & $\begin{array}{c}\text { strategic } \\
\text { performance } \\
\text { using } \\
\text { Balanced } \\
\text { Scorecard }\end{array}$ \\
\hline
\end{tabular}

Subsequently, we noticed from the data in the table above that the arithmetic mean of the availability of integrated measures to evaluate the strategic performance using Balanced Scorecard in Amman Municipality was 3.0884. Thus, this is larger than the default arithmetic mean adopted by a researcher (3). The difference is 0.0884 . Such difference is not significance based on the value of significance (Sig $=0.065$ ) which is greater than 0.5. This difference indicates disapproving the availability of integrated measures to evaluate the strategic performance using Balanced Scorecard. It also accepts the second major hypothesis, which states that integrated measures to evaluate the strategic performance using Balanced Scorecard are not available.

H03: Applying balanced scorecard does not improve the efficiency of the strategic performance.

Table (10). Testing the third major hypotheses

\begin{tabular}{|c|c|c|c|c|c|}
\hline $\begin{array}{c}\text { Intangible } \\
\text { Sig }\end{array}$ & $\begin{array}{c}\text { The } \\
\text { calculated } \\
\text { value of } T \\
\end{array}$ & $\begin{array}{l}\text { Standard } \\
\text { deviation }\end{array}$ & $\begin{array}{c}\text { Arithmetic } \\
\text { mean } \\
\text { value }\end{array}$ & $\begin{array}{c}\text { Arithmetic } \\
\text { mean } \\
\text { difference }\end{array}$ & $\begin{array}{l}\text { Applying Balanced } \\
\text { Scorecard improves } \\
\text { the efficiency of the }\end{array}$ \\
\hline 0.000 & 5.473 & 0.88063 & 3.3185 & 0.31849 & $\begin{array}{c}\text { strategic } \\
\text { performance. }\end{array}$ \\
\hline
\end{tabular}

Subsequently, we noticed from the data in the table above that the arithmetic mean of the third major hypothesis was 3.3185. Thus, this is larger than the default arithmetic mean adopted by a researcher (3). The difference is 0.31849. Such difference is considered significance based on the value of significance (Sig $=0.000$ ) which is smaller than 0.5. Such difference approves that applying Balanced Scorecard improves the efficiency of the strategic performance. It also rejects the third major 
hypotheses and accepts the alternative hypotheses, which states that applying Balanced Scorecard improves the efficiency of the strategic performance.

H04: Applying Balanced Scorecard does not improve the effectiveness of the strategic performance.

Table (11). Testing the fourth major hypotheses

\begin{tabular}{|c|c|c|c|c|c|}
\hline $\begin{array}{c}\text { Intangible } \\
\text { Sig }\end{array}$ & $\begin{array}{c}\text { The } \\
\text { calculated } \\
\text { value of T }\end{array}$ & $\begin{array}{c}\text { Standard } \\
\text { deviation }\end{array}$ & $\begin{array}{c}\text { Arithmetic } \\
\text { mean } \\
\text { value }\end{array}$ & $\begin{array}{c}\text { Arithmetic } \\
\text { mean } \\
\text { difference }\end{array}$ & $\begin{array}{c}\text { Applying Balanced Scorecard } \\
\text { improves the effectiveness of } \\
\text { the strategic performance. }\end{array}$ \\
\hline $\mathbf{0 . 0 0 0}$ & $\mathbf{5 . 9 6 9}$ & $\mathbf{0 . 9 5 6 5 1}$ & $\mathbf{3 . 3 7 7 3}$ & $\mathbf{0 . 3 7 7 2 6}$ & the \\
\hline
\end{tabular}

Subsequently, we noticed from the data in the table above that the arithmetic mean of the fourth major hypothesis was 3.3773. Thus, this is larger than the default arithmetic mean adopted by a researcher (3). The difference is 0.37726 . Such difference is significance based on the value of significance (Sig $=0.000$ ) which is smaller than 0.5. Such difference approves that applying Balanced Scorecard improves the effectiveness of the strategic performance. It also rejects the fourth major hypotheses and accepts the alternative hypotheses, which states that applying Balanced Scorecard improves the effectiveness of the strategic performance.

H03: There is no statistical significant effect of applying Balanced Scorecard measures on the strategic performance efficiency.

In order to test the general hypotheses of the study, Multiple Linear Regression was used. The results are as follows:

Table (13). Test results of the existence of statistical significant effect of applying Balanced Scorecard measures on the strategic performance efficiency

\begin{tabular}{|c|c|c|c|c|c|c|c|c|c|}
\hline \multicolumn{5}{|c|}{ Regression coefficients } & \multirow[b]{2}{*}{$\begin{array}{c}\text { Sig } \\
\text { F }\end{array}$} & \multirow[b]{2}{*}{$\begin{array}{l}\text { Calculat } \\
\text { ed } \\
\text { F }\end{array}$} & \multirow{2}{*}{$\begin{array}{c}\text { R2 } \\
\text { Coefficien } \\
\text { t of } \\
\text { determinat } \\
\text { ion } \\
\end{array}$} & \multirow{2}{*}{$\begin{array}{c}\mathrm{R} \\
\text { Correlati } \\
\text { on } \\
\text { coefficie } \\
\text { nt }\end{array}$} & \multirow[b]{2}{*}{$\begin{array}{l}\text { Dependen } \\
\text { t variable }\end{array}$} \\
\hline $\begin{array}{c}\text { Sig } \\
\mathrm{t}\end{array}$ & $\mathrm{T}$ & $\begin{array}{l}\text { Standa } \\
\text { rd } \\
\text { error }\end{array}$ & $\beta$ & Perspective & & & & & \\
\hline $\begin{array}{c}0.00 \\
0\end{array}$ & $\begin{array}{c}3.91 \\
1\end{array}$ & 0.044 & $\begin{array}{c}0.17 \\
4\end{array}$ & $\begin{array}{l}\text { Learning } \\
\text { and Growth }\end{array}$ & \multirow{5}{*}{$\begin{array}{c}0.00 \\
0\end{array}$} & \multirow{5}{*}{95.452} & \multirow{5}{*}{0.547} & \multirow{5}{*}{0.739} & \multirow{5}{*}{$\begin{array}{c}\text { Strategic } \\
\text { performa } \\
\text { nce } \\
\text { Efficienc } \\
\text { y. }\end{array}$} \\
\hline $\begin{array}{c}0.00 \\
0\end{array}$ & $\begin{array}{c}3.86 \\
2\end{array}$ & 0.057 & $\begin{array}{c}0.22 \\
2\end{array}$ & Customer & & & & & \\
\hline $\begin{array}{c}0.00 \\
0\end{array}$ & $\begin{array}{c}4.65 \\
5\end{array}$ & 0.068 & $\begin{array}{c}0.31 \\
7\end{array}$ & $\begin{array}{c}\text { Internal } \\
\text { Processes }\end{array}$ & & & & & \\
\hline $\begin{array}{c}0.00 \\
0\end{array}$ & $\begin{array}{c}4.87 \\
6\end{array}$ & 0.055 & $\begin{array}{c}0.26 \\
7\end{array}$ & Financial & & & & & \\
\hline $\begin{array}{c}0.76 \\
8\end{array}$ & $\begin{array}{c}- \\
0.29 \\
6\end{array}$ & 0.067 & $\begin{array}{c}- \\
0.02 \\
0\end{array}$ & $\begin{array}{l}\text { Environme } \\
\text { ntal }\end{array}$ & & & & & \\
\hline
\end{tabular}

* The effect is statistically significant at the level of $\alpha \leq 0.05$

The results of the table above indicate that the impact of the independent variables (Balanced Scorecard perspectives) on the dependent variable (Strategic performance efficiency) is a statistical significant impact. The calculated F value is 95.452, and the level of significance is given as Sig 
$\mathrm{F}=0.000$, which is less than 0.05. Consequently, the correlation coefficient $(\mathrm{R}=0.739)$ refers to a positive relationship between the independent variables and the dependent variable. In addition, coefficient of determination value is given as R2 $=0.547$. This, however, points out that $54.7 \%$ of the variation in the Strategic Performance Efficiency can be explained by the variation in the Balanced Scorecard Perspectives. Furthermore, the regression coefficient is shown below:

The value of $\beta$ (learning and growth perspective) has reached 0.174 , the value of $t$ is 3.911, and the level of significance is Sig $=0.000$. The value of $\beta$ (customer perspective) amounted to 0.222 , the value of $t$ is 3.862 , and the level of significance is $\operatorname{Sig}=0.000$. The value of $\beta$ at Internal Processes Perspective is 0.317 , the value of $t$ is 4.876 , and the level of significance is $\operatorname{Sig}=0.000$. The value of $\beta$ (financial perspective) amounted to 0.267 , the value of $t$ is 4.876, and the level of significance is Sig $=0.000$. This indicates that these perspectives have intangible impact. Finally, $\beta$ (environmental perspective) was -0.020 , the value of $t$ then was -0.296 , and the level of significance is Sig $=0.768$ which is greater than 0.05 . This indicates that the impact of this perspective is insignificant on the efficiency of strategic performance when studying the Balanced Scorecard perspectives together. Accordingly, we reject the third main hypotheses and accept the alternative one, which states that: There is statistical significant effect of applying Balanced Scorecard measures on the strategic performance effectiveness.

H04: There is no statistical significant effect of applying Balanced Scorecard measures on the strategic performance efficiency.

In order to test the general hypothesis of the study, Multiple Linear Regression was used. The results are as follows:

Table (13). Test results of the existence of statistical significant effect of applying Balanced

Scorecard measures on the strategic performance effectiveness

\begin{tabular}{|c|c|c|c|c|c|c|c|c|c|}
\hline \multicolumn{5}{|c|}{ Regression Coefficients } & \multirow[b]{2}{*}{$\begin{array}{c}\text { Sig } \\
\text { F }\end{array}$} & \multirow{2}{*}{$\begin{array}{c}\text { Calculat } \\
\text { ed } \\
\text { F }\end{array}$} & \multirow{2}{*}{$\begin{array}{c}\mathrm{R} 2 \\
\text { coefficient } \\
\text { of } \\
\text { determinat } \\
\text { ion } \\
\end{array}$} & \multirow{2}{*}{$\begin{array}{c}\mathrm{R} \\
\text { correlati } \\
\text { on } \\
\text { coeffici } \\
\text { ent } \\
\end{array}$} & \multirow[b]{2}{*}{$\begin{array}{l}\text { Dependen } \\
\text { t variable }\end{array}$} \\
\hline $\begin{array}{c}\text { Sig } \\
\mathrm{t}\end{array}$ & $\mathrm{T}$ & $\begin{array}{l}\text { Standa } \\
\text { rd } \\
\text { error }\end{array}$ & $\beta$ & Perspective & & & & & \\
\hline $\begin{array}{c}0.45 \\
8\end{array}$ & $\begin{array}{c}0.74 \\
4\end{array}$ & 0.076 & $\begin{array}{c}0.05 \\
6\end{array}$ & $\begin{array}{c}\text { Learning } \\
\text { and Growth }\end{array}$ & \multirow{5}{*}{$\begin{array}{c}0.00 \\
0\end{array}$} & \multirow{5}{*}{54.722} & \multirow{5}{*}{0.551} & \multirow{5}{*}{0.742} & \multirow{5}{*}{$\begin{array}{l}\text { Strategic } \\
\text { performan } \\
\text { ce } \\
\text { effectiven } \\
\text { ess }\end{array}$} \\
\hline $\begin{array}{c}0.00 \\
0\end{array}$ & $\begin{array}{c}5.28 \\
3 \\
\end{array}$ & 0.058 & $\begin{array}{c}0.30 \\
4 \\
\end{array}$ & Customer & & & & & \\
\hline $\begin{array}{c}0.00 \\
1 \\
\end{array}$ & $\begin{array}{c}3.31 \\
7 \\
\end{array}$ & 0.072 & $\begin{array}{c}0.24 \\
0 \\
\end{array}$ & $\begin{array}{c}\text { Internal } \\
\text { Processes }\end{array}$ & & & & & \\
\hline $\begin{array}{c}0.00 \\
2 \\
\end{array}$ & $\begin{array}{c}3.18 \\
2 \\
\end{array}$ & 0.058 & $\begin{array}{c}0.18 \\
4 \\
\end{array}$ & Financial & & & & & \\
\hline $\begin{array}{c}0.81 \\
2\end{array}$ & $\begin{array}{c}- \\
0.23 \\
9\end{array}$ & 0.043 & $\begin{array}{c}- \\
0.01 \\
0\end{array}$ & $\begin{array}{c}\text { Environme } \\
\text { ntal }\end{array}$ & & & & & \\
\hline
\end{tabular}

* The effect is statistically significant at the level of $\alpha \leq 0.05$ 
Consequently, the results of the table above indicate that the impact of the independent variables (Balanced Scorecard perspectives) on the dependent variable (Strategic performance effectiveness) is a statistical significant impact. The calculated $F$ value is 54.722, and the level of significance is Sig F $=0.000$, which is less than 0.05. On the other hand, the correlation coefficient $(\mathrm{R}=0.742)$ refers to a positive relationship between the independent variables and the dependent variable. In addition, coefficient of determination value was given as R2 $=0.551$. Therefore, this point out that $55.1 \%$ of the variation in the Strategic Performance Effectiveness can be explained by the variation in the Balanced Scorecard Perspectives. The regression coefficients showed the following: The value of $\beta$ (learning and growth perspective) has reached 0.056 , the value of $t$ is 0.744 , and the level of significance is Sig $=0.458$. This indicates that the impact of this perspective is insignificant. The value of $\beta$ (customer perspective) amounted to 0.304 , the value of $t$ is 5.283 , and the level of significance is given as Sig $=0.000$. The value of $\beta$ (internal processes perspective) is 0.240 , the value of $t$ is 3.317, and the level of significance is given as Sig $=0.001$. The value of $\beta$ (financial perspective) amounted to 0.184 , the value of $t$ is 3.182 , and the level of significance is given as Sig $=0.002$. This indicates that these perspectives have significant impact. Finally, $\beta$ (environmental perspective) was -0.010 , the value of $t$ then was -0.239 , and the level of significance is given as Sig $=0.812$ which is greater than 0.05 . Therefore, this indicates the absence of the significant effect of this perspective based on the effectiveness of strategic performance when studying Balanced Scorecard perspectives together. Accordingly, we reject the forth main hypothesis and accept the alternative one, which states that: There is statistical significant effect of applying Balanced Scorecard measures on the strategic performance effectiveness.

\section{Conclusions and Recommendations Conclusions}

The findings of the study are summarized as follows:

1. Greater Amman Municipality has its own strategy that agrees with the national goals and was translated into strategic objectives. The starting point of this municipality strategy was prepared in the first strategic plan (2002-2006). Its objectives were set out according to the national agenda and "We Are All Jordan" initiative. Therefore, this was obvious when personal interviews were conducted with those concerned in the Municipality. This confirms that public sector organizations have a strategic planning philosophy which is different from private sector organizations. Thus, this is because private sector organizations mission includes programs and initiatives, whereas public sector organizations have specific objectives to 
achieve such as maximizing shareholder value. Also, this result agrees with the study of Kaplan and Norton (2001).

2. Balanced Scorecard application requirements are not available in Greater Amman Municipality, including:

A. The lack of incentives and rewards system in Greater Amman Municipality which impedes Balanced Scorecard application.

B. The lack of awareness among the workers regarding the use and application of Balanced Scorecard.

C. The lack of expertise among workers in the use and application of the Balanced Scorecard.

Scorecard.

D. Lack of training in the use and application of the Balanced

3. Greater Amman Municipality focuses on the use of certain measures of Balanced Scorecard in the evaluation of strategic performance such as the growth in collecting own revenues and neglecting other measures such as cost control and service efficiency delivery measures.

4. The five Balanced Scorecard perspectives vary in their use in Amman Municipality. Here the financial perspective rank is the first, followed by the customer perspective, then internal processes perspective, then learning and growth perspective, and lastly the environmental perspective.

5. The Study results indicate that the use of the Balanced Scorecard perspectives leads to improvement in the efficiency of strategic performance. However, these perspectives can be classified according to their strength of impact on the strategic performance of Amman Municipality as follows: Costumer perspective is the most influential, then followed by financial perspective. In addition, adding the environmental perspective to the four Balanced Scorecard perspectives, as designed by Kaplan and Norton, did not affect the efficiency of the strategic performance in Greater Amman Municipality due to the stakeholders' lack of awareness of the importance of this perspective. Furthermore, it is worth mentioning that the general measure of the use of environmental perspective in Amman Municipality reached $60.34 \%$.

6. Balanced Scorecard perspectives improve the effectiveness of Amman Municipality strategic performance. The results indicated that customer perspective has the greatest impact on the effectiveness of strategic performance. In addition, Amman Municipality provides services specified by the law, and adopts social initiatives in partnership with the private sector through sophisticated systems and electronic devices which positively impact the strategic performance effectiveness in Amman Municipality. In addition, learning and growth perspective has no effect on the strategic performance due to the lack of training and human resources welfare 
programs. In addition to this is the lack of clear job descriptions. The study also found that there is no effect of the environmental dimension on the effectiveness of strategic performance in Amman Municipality because of the lack of activating relationships with strategic partners, initiatives, and projects related to this perspective.

\section{Recommendations}

1- $\quad$ The need to implement Balanced Scorecard for evaluating strategic performance in Greater Amman Municipality through:

A. Conducting specialized training courses on strategic planning and the use of Balanced Scorecard, which will enhance cognitive dimension of the human resources in Greater Amman Municipality regarding strategic planning and the use of Balanced Scorecard as a tool of modern management accounting.

B. Increasing Senior Management awareness of adopting Balanced Scorecard which would contribute to the success of work programs.

C. Enhancing the participation of Greater Amman Municipality workers in the formulation and implementation of the goals to activate the decisionmaking process.

D. Completing the organizational structure of Greater Amman Municipality, and clarifying responsibilities, duties, and job descriptions for all job titles.

E. Linking all electronic systems in the Greater Amman Municipality which leads to the provision of reliable data and some measures results electronically.

F. Linking material and moral incentives system together in order to achieve pre-set objectives for the directorates and departments.

G. Choosing the right performance measures that suit the nature of work of the Municipality and that reflects the perspectives of Balanced Scorecard.

$\mathrm{H}$. Reinforcing some items in the annual evaluation model for Greater Amman Municipality employees' performance which is related to the contribution in achieving the strategic objectives and the knowledge transfer in strategic planning and Balanced Scorecard use.

2. Paying attention to learning and growth perspective because of its impact on raising the efficiency of strategic performance through:

A. Developing Greater Amman Municipality workers' skills through specialized training courses to increase the speed of service delivery and reduce errors in providing services.

B. Providing suitable working environment that includes clean buildings divided into offices with space that commensurate with the volume of services provided and the number of the staff in the office besides offering service requirements, information technology, health facilities, and cafeteria 
and public facilities. Thus, this will be reflected positively on increasing employee loyalty.

C. Activating incentives and rewards system and linking it to the number of proposals submitted by the employee and the contribution of this proposal towards the completion of specific goals.

D. Linking all systems in Greater Amman Municipality with each other and providing sophisticated electronic devices.

E. Paying attention to other organizations experiences who work in the same field. This will contribute to the development of processes and the provision of services in the best way.

3. Making the necessary modifications on Balanced Scorecard model by Kaplan and Norton to meet the work of the Municipality besides giving the customer perspective the greatest weight because of its impact on the effectiveness and efficiency of the strategic performance.

4. Paying attention to the environmental perspective and environmental performance indicators in Greater Amman Municipality, through:

A. Determining the directorates and departments directly related to the environmental projects.

B. Identifying strategies and strategic objectives of the environmental perspective and activating the proposed measures for this perspective besides developing a plan of actions and programs regarding the strategic objectives of this perspective.

C. Preparing a document on the importance of environmental projects, and distributing it to customers and those concerned in the environmental projects.

D. Conducting regular meetings with stakeholders in Amman Municipality to set up environmental projects and programs (such as electricity, water etc.) besides following up the implementation of these programs.

E. Access to similar international experiences and practices regarding the environmental perspective in order to take advantage and make improvements in the established programs.

F. Conducting surveys on a regular basis with Amman customers and visitors to inquire about their level of satisfaction regarding the environmental services.

8. Paying attention to scientific research on the use of Balanced Scorecard to evaluate strategic performance in the government sector. This is because this sector provides knowledge references that can serve as a guide to improve the strategic planning process. 
References:

1. AL Doury, Z, (2005). "Strategic Management: Concepts, processes and Case Studies”, Dar Yazouri Publishing, Amman,Jordan.

2. AL Dajani, E (2011). "The Role of Strategic Planning in the Institutional Quality of Performance, the Study of Descriptive and Analytical in the Palestinian Regular Universities", $\mathrm{PhD}$ Thesis, University of Damascus, Syria.

3. Akel .M. (2002). "The Balanced Scorecard on the Internet at http//www.JPS-dir.com.

4. Atkinson, H (2006), "Strategy Implementation a Role for the Balanced Scorecard”, Emerald Group Publishing Limited, Vol. 44, No. 10.

5. AL salem A. "The Impact of Applying the Balanced Performance Measurement to Meaure the Institutional Commitment Among Workers in the Jordan customs Department”, Unpublished Master Thesis,

6. AL shaikh Ali \& Mohammed .N, (2007). “Performance Evaluation of Palestinian Telecommunication Corporations by Using Balanced Scorecard Approach “,Unpublished master college of commerce, Islamic University ,Gaza, Palestine .

7. Boulianne, E. (2013). "The Balanced Scorecard Concept and its Dimensions Weighting Scheme”, CGA Research centre John Molson School of Business-Concordia University.

8. Chan,Y. (2004). "Performance Measurement and Adoption of Balanced Scorecards : A Survey of Municipal Government in the USA and Canada”, The International Journal of Public Sector Management ,Vol.17,No.2/3,pp 204-221.

9. Ghoneim, O (2001). “The Foundations and Principles of Planning”, The second edition, Dar Al Reda for Publishing and Distribution, Amman, Jordan.

10. Gomes, Ricardo C. Liddle, Joyce \& Veloso C. Raissa (2008). "Performance Appraisal in Brazilian Small-Scale Municipalities: Using the Balanced Scorecard as a Feasible tool", ANBAD, Salvador.

11. Horngren, C. T., Foster, G., \& Dater, S. (2009). “Cost Accounting Managerial Emphasis”, $13^{\text {th }}$ ed., Prentice- Hall.

12. Kamal alddin, J, (2013). "The Use of the Balanced Scorecard to Measure the Performance of the Strategic Plan”, A working paper presented at a training workshop at the University of Princess Noura Abdurrahman for Girl - Riyadh. 
13. Kaplan, Robert S. \& Norton, David P., (2001). "Transforming the Balanced Scorecard from performance Measurement to Strategic Management ": part 2. Accounting Horizons

14. Kaplan, Robert S. \& Norton, David P., (1992). "The Balanced Scorecard Measures that Drive Performance". Harvard Business Review, Vol.70.

15. Kaplan, Robert S. and Norton, David P. (1996). "Using the Balanced Scorecard as a Strategic Management System Building a Scorecard Can Help Manager Link Today's Action with Build Tomorrows Goals”, Harvard Business Review.

16. Kaplan, Robert, Young S. Mark \& Atkinsom A. Anthony (2004). “Advanced Management Accounting” ,4 th ed. prentice-hall, NewJersy.

17. Kaplan, Robert \& Atkinsom A. Anthony (1998). “Advanced Management Accounting”, $3^{\text {th }}$ ed. prentice-hall, NewJersy.

18. McGinty, R (2004). "Measuring Business Performance Emerging Perspectives of the Balanced Scorecard" , Journal of Business and Economics Research, Vo1. 2, No. 5.

19. Niven, P. (2003). "Balanced Scorecard Step by Step for Government and Non-profit Agencies”, John Wiley \& Sons, New York.

20. Northcott .D, (2011). "Using the Balanced Scorecard to Manage performance in public Sector Organizations-Issues and Challenges", International Journal of Public Sector Management ,Vol.25,pp.166-191.

21. Pankaj.C (2013). "Balanced Scorecard as Strategic Management System : A Case Study about Employees a Wariness and Perceptions Towards BSC”, International Journal of Research in IT \& Management,Vol.3,pp.90-97.

22. Shahin, Dolatobadi, \& Kouchekian , M. (2012). "Proposing an Integrated Model of (BSC) and (EFQM) and Analyzing its Influence on Organizational Strategies and Performance :the Case of Isfahan Municipality Complex ", International Journal of academic Research in Economic and Management sciences ,Vol.1, No.3.

23. Turkman, A. (2006). "The Correction Balanced Scorecard as a Tool for Measuring Performance”, Tishreen University Journal for Studies and Scientific Research, a series of economic and legal sciences, Damascus, Syria, Volume 28, No. 1.

24. Weich, A \& Al khan, A. (2010). "Implementing Balanced Scorecard in a Municipality Setting - and They Lived Happily Ever After? A Case Study of the City of Copenhagen”, Lund university. pp 1-63. 
25. Zipporah Karimi Muiruvi \& James Kilika (2015). “The Influence of the Balanced Score Card on Performance of Public Sector Organizations in Kenya", Science Journal of Business and Management, Vol .3., No. 5 ,pages 150-156. 